\title{
KARAKTERISTIK MUTU KIMIA DAN MIKROBIOLOGI GURITA (Octopus sp.) KERING YANG DIPASARKAN DIKABUPATEN KONAWE UTARA SULAWESI TENGGARA
}

\author{
Chemical and Microbiological Quality Characteristics of Dried Octopus (Octopus sp.) Marketed in North Konawe \\ Regency Southeast Sulawesi
}

\author{
Asman*, Kobajashi T. Isamu, Suwarjoyowirayatno \\ Jurusan Teknologi Hasil Perikanan, Fakultas Perikanan dan Ilmu Kelautan Universitas Halu Oleo, Kendari, \\ Sulawesi Tenggara, Indonesia
}

*Email korespondensi: asmannub003@gmail.com (Telp: +6285240285747)

Diterima: 10 Januari/ Disetujui 15 Maret 2020

Cara sitasi: Asman, Isamu KT, Suwarjoyowirayatno. 2020. Karakteristik mutu kimia dan mikrobiologi gurita (Octopus sp.) kering yang dipasarkan di Kabupaten Konawe Utara Sulawesi Tenggara. Jurnal Fish Protech. 3(1):120-124.

\section{ABSTRACT}

The aim of this study was to determine the characteristics of chemical composition (water, ash, protein, fat, and carbohydrate) and total bacteria (TPC) of dried Octopus. Data analysis of this study used descriptive analysis. The sampling technique of this study are used simple random sampling, and used the survey method. The results of the highest chemical composition of the treatment was found at water content S1 19.89\%, ash S3 13.63\%, protein S2 46.99\%, fat S3 $5.82 \%$ and carbohydrate S2 10.19\%. The best Total Plate Count (TPC) result was found at S2 $3.8 \times 10^{4} \mathrm{Cfu} / \mathrm{g}$

Keywords: Chemical Test, Octopus (Octopus sp.) Dry, and Total Plate Count (TPC).

\begin{abstract}
ABSTRAK
Tujuan penelitian ini adalah untuk mengetahui karakteristik komposisi kimia (kadar air, kadar abu, kadar protein, kadar lemak, dan kadar karbohidrat) dan total bakteri (TPC) terhadap gurita kering. Analisis data yang digunakan dalam penelitian ini yaitu menggunakan analisis deskriptif. Teknik sampling yang digunakan pada penelitian ini adalah simple random sampling. Metode yang digunakan pada penelitian ini yaitu metode survei. Hasil penelitian komposisi kimia perlakuan tertinggi kadar air terdapat pada S1 19.89\%, kadar abu tertinggi terdapat pada perlakuan S3 $13.63 \%$, kadar protein perlakuan tertinggi terdapat pada S2 $46.99 \%$, kadar lemak perlakuan tertinggi terdapat pada S3 $5.82 \%$ dan kadar karbohidrat perlakuan tertinggi terdapat pada S2 $10.19 \%$. Hasil Uji Total Plate Count (TPC) terendah terdapat pada S2 $3.8 \times 10^{4} \mathrm{Cfu} / \mathrm{g}$.
\end{abstract}

Kata kunci: Gurita (Octopus sp.) kering, Total Plate Count (TPC) dan Uji Kimia.

\section{PENDAHULUAN}

Data Pelabuhan Perikanan Samudera Kendari, jumlah ekspor gurita setiap bulannya sepanjang tahun 2011 berfluktuasi tergantung pada musim tangkap. Sepanjang tahun terdapat empat kali musim tangkap puncak yaitu di bulan Maret, Mei, Oktober, dan November. Oleh sebab itu, total ekspor pada bulanbulan tersebut mayoritas sangat tinggi, mencapai diatas 100 ton (KKP, 2011).
Apabila dilihat dari nilai ekspor, sepanjang tahun 2011 nilai ekspor gurita mengalami kenaikan rata-rata sebesar $49,69 \%$, dengan nilai ekspor tertinggi adalah $\mathrm{Rp} 5.779 .350 .000$,- di bulan November (KKP, 2011). Pelabuhan perikanan samudera kendari memberikan kontribusi besar dalam pengolahan hasil sumber daya kelautan dan perikanan Sulawesi Tenggara. Kontribusi tersebut berupa 
meningkatnya produksi komoditi unggulan laut di Sulawesi Tenggara seperti, udang, cakalang, kakap merah, tuna dan gurita. Gurita menjadi komoditas yang paling laris diekspor mencapai 525,80 ton per triwulan (KKP, 2018). Kenaikan nilai ekspor tersebut disebabkan tingginya permintaan gurita di pasar Amerika Serikat, Jepang, dan Uni Eropa.

Gurita saat ini menjadi salah satu makanan hasil laut yang banyak digemari baik oleh konsumen lokal maupun konsumen internasional. Indonesia saat ini berada diperingkat ke-11 sebagai pengekspor gurita ke Jepang pada Tahun 2012 (KKP, 2012). Gurita memiliki potensi sumber daya laut yang menjadi komoditi unggulan bagi para nelayan dan pengusaha perikanan di

Kota Kendari selain ikan tuna (Listiani, 2013).

Gurita merupakan salah satu sumber daya hayati laut yang memiliki potensi yang besar. Gurita memiliki kandungan protein yang cukup tinggi sehingga mempunyai potensi dalam penyediaan bahan makanan bagi kehidupan manusia, diantaranya ada tiga jenis yang dikenal sebagai bahan makanan yang lezat yaitu Octopus vulgaris, Octopus ocellatus dan Paraoctopus dofleni (Winarko, 2001). Mutu produk olahan gurita yang baik berasal dari mutu bahan mentah yang segar dan belum mengalami proses pembusukan, tetapi mutu produk olahan yang tidak baik berasal dari mutu bahan mentah yang tidak segar dan telah mengalami proses penguraian senyawasenyawa didalam tubuh gurita sehingga mutu olahan menjadi rendah. Untuk memperpanjang mutu, diperlukan pengolahan dan pengawetan untuk mencegah pembusukan (Adawyah, 2008).

Pengolahan dan pengawetan merupakan usaha untuk meningkatkan kualitas dan daya awet produk perikanan pasca panen.

Pengeringan sudah dilakukan pada zaman dahulu dengan berbagai tujuan antara lain untuk memperpanjang umur penyimpanan, meningkatkan mutu, mengurangi kerugian saat panen, memudahkan pemasaran, dan menjamin ketersediaan produk yang bersifat musiman. Di negara-negara tropis seperti Indonesia, pengawetan produk dengan cara pengeringan merupakan metode yang umum dilakukan (Abdurrachim, 2009).

Salah satu permasalahan konsumen saat membeli produk gurita kering yang dipasarkan di Kabupaten Konawe Utara yaitu adanya produk yang tidak dikeringkan secara merata ada beberapa yang hanya setengah kering tetapi sudah dipasarkan, hal ini akibat kondisi cuaca yang tidak menentu dan proses pengolahan yang kurang baik. Berdasarkan hasil tersebut mendasari dilakukannya penelitian tentang Karakteristik mutu kimia dan mikrobiologi gurita kering yang dipasarkan di Kabupaten Konawe Utara Sulawesi Tenggara.

\section{METODE PENELITIAN}

\section{Alat dan Bahan}

Alat yang digunakan pada penelitian ini adalah, pada proses pengeringan (para-para dan meja). Alat untuk analisis kimia meliputi: tabung reaksi (Iwaki), spektrofotometer UV-VIS (Shimadzu), vortex (Ika), timbangan analitik (Fijitsu), hot-plate, gelas piala, gelas ukur, batang pengaduk, pipet tetes, pipet mikro (Dragonlab micropipette), corong, tabung reaksi, labu takar, erlenmeyer (Pyrex), dan alat destilasi (Pyrex). Alat untuk analisis mikrobiologi meliputi: Alat bedah (Golg Cross), cawan petri, pipet hisap ( Vitlab), tabung Erlenmeyer (Pyrex), tabung reaksi (Iwaki), spritus, dan incubator (Faithful).

Bahan yang digunakan pada penelitian adalah gurita kering yang diambil di Kabupaten Konawe Utara. Bahan analisis yang digunakan yaitu aquades, $\mathrm{HNO}_{3}, \mathrm{HClO}_{4}$, serbuk $\mathrm{Ca}\left(\mathrm{NO}_{3}\right)_{2}$, $\mathrm{NaNO}_{3}$, dan $\mathrm{PO}_{4}{ }^{3-}$, asam nitrat $\left(\mathrm{HNO}_{3}\right)$ pekat, dan asam klorida $(\mathrm{HCl})$ pekat.

\section{Metode pengambilan sampel}

Metode yang digunakan dalam penelitian ini yaitu metode pengambilan sampling acak sederhana (Simple Random Sampling) disertai wawancara. Pengambilan sampel yang dilakukan dari beberapa pedagang yang ada di Desa Bandaeha (S1), Desa Barasanga (S2), dan Desa Laimeo (S3) tiap sampel yang diambil sebanyak $1 \mathrm{~kg}$ dan kemudian dibawa di Laboratorium untuk dilakukan pengujian. 


\section{Parameter uji}

Analisis uji kimia meliputi kadar air, kadar abu, kadar protein, kadar lemak dan kadar karbohidrat dan Analisis uji Total Plate Count (TPC).

\section{Analisis data}

Analisis data penelitian ini menggunakan analisis dekriptif. Analisis deskriptif pada penelitian ini digunakan untuk memberikan gambaran umum tentang data yang telah diperoleh.

\section{HASIL DAN PEMBAHASAN}

Berdasarkan hasil penelitian tentang analisis uji kimia gurita kering yang dipasarkan di Kabupaten Konawe Utara Sulawesi Tenggara dapat dilihat pada Tabel 1.

Tabel 1. Analisis uji kimia

\begin{tabular}{|c|c|c|c|c|c|c|}
\hline \multirow{2}{*}{\multicolumn{2}{|c|}{ Kode sampel }} & \multicolumn{5}{|c|}{ Hasil Uji } \\
\hline & & $\begin{array}{c}\text { Kadar Air } \\
(\%)\end{array}$ & $\begin{array}{c}\text { Kadar } \\
\text { Abu (\%) }\end{array}$ & $\begin{array}{c}\text { Kadar } \\
\text { Protein } \\
(\%)\end{array}$ & $\begin{array}{c}\text { Kadar } \\
\text { Lemak } \\
(\%)\end{array}$ & $\begin{array}{c}\text { Kadar } \\
\text { Karbohidrat } \\
(\%)\end{array}$ \\
\hline S1 & & 18.99 & 8.11 & 45.97 & 4.28 & 6.32 \\
\hline S2 & & 17.13 & 13.63 & 46.99 & 4.64 & 10.19 \\
\hline S3 & & 19.89 & 8.65 & 42.39 & 5.82 & 9.63 \\
\hline
\end{tabular}

Berdasarkan hasil penelitian tentang analisis Total Plate Count (TPC) gurita kering yang dipasarkan di Kabupaten Konawe Utara Sulawesi Tenggara dapat dilihat pada Tabel 2.

Tabel 2. Analisis Total Plate count (TPC)

\begin{tabular}{lll}
\hline Kode Sampel & Hasil Uji (Cfu/g) & Standar SNI \\
& & $2771: 2009(\mathrm{Cfu} / \mathrm{g})$ \\
\hline S1 & $8.5 \times 10^{4}$ & $1 \times 10^{5}$ \\
S2 & $3.8 \times 10^{4}$ & $1 \times 10^{5}$ \\
S3 & $6.7 \times 10^{4}$ & $1 \times 10^{5}$ \\
\hline
\end{tabular}

\section{Uji Kimia}

\section{Kadar Air}

Hasil analisis kadar air tertinggi (Tabel 1 ) terdapat pada S3 dengan nilai $19,89 \%$ dan nilai terendah pada S2 dengan nilai $17,13 \%$. Nilai tersebut lebih rendah dibandingkan penelitian Thanonkaew et al. (2006) menyatakan kandungan pada kadar air gurita berkisar antara 48,42 dan $82,78 \%$. Rendahnya rerata nilai dari ketiga sampel tersebut dikarenakan bahan baku yang diambil dalam bentuk kering atau sudah melewati proses pengeringan, sehingga kadar airnya lebih rendah. Wirakartakusumah (1992), pengeringan merupakan operasi pengurangan kadar air bahan padat sampai batas tertentu sehingga bahan tersebut bebas terhadap serangan mikroorganisme, enzim, dan insekta yang merusak. Secara lebih luas, pengeringan merupakan proses yang terjadi secara stimultan (serempak) antara perpindahan panas dari udara pengeringan ke bahan yang dikeringkan dan terjadi penguapan air dari bahan yang dikeringkan. 


\section{Kadar Abu}

Hasil analisis kadar abu tertinggi (Tabel 1) terdapat pada S2 dengan nilai $13,63 \%$ dan nilai terendah pada S1 dengan nilai $8,11 \%$. Hasil tersebut lebih tinggi dibandingkan penelitian Thanonkaew et al. (2006) yang menyatakan kandungan pada kadar abu gurita berkisar antara 1,29-1,20\%. Kadar abu juga dipengaruhi oleh suhu dan lamanya pengeringan. Riansyah et al., (2013) menyatakan semakin tinggi suhu dan lamanya waktu yang digunakan selama pengeringan maka akan semakin meningkatkan kadar abu.

\section{Kadar Protein}

Hasil analisis kadar protein tertinggi (Tabel 1) terdapat pada S2 dengan nilai $46,99 \%$ dan nilai terendah pada S3 dengan nilai $42,39 \%$. Hasil tersebut lebih tinggi dibandingkan penelitian Thanonkaew et al. (2006) yang menyatakan kandungan pada kadar protein gurita berkisar antara $11,90-14,91 \%$. Hal ini diduga karena proses pengeringan yang dilakukan, yang menyebabkan kandungan air pada bahan baku menurun sehingga protein meningkat. Menurut Adawyah (2007) kadar air yang mengalami penurunan akan mengakibatkan kandungan protein didalam bahan mengalami peningkatan. Penggunaan panas dalam pengolahan bahan pangan dapat menurunkan persentase kadar air yang mengakibatkan persentase kadar protein meningkat.

\section{Kadar Lemak}

Hasil analisis kadar lemak tertinggi (Tabel 1) terdapat pada S3 dengan nilai $5,82 \%$ dan nilai terendah pada $\mathrm{S} 1$ dengan nilai $4,28 \%$. Hasil tersebut lebih tinggi dibandingkan penelitian Thanonkaew et al. (2006) yang menyatakan kandungan pada kadar lemak gurita berkisar antara 0,52-0,47\%. Sejalan dengan penelitian Yuniarti (2007), yang menyatakan bahwa dengan lamanya waktu dan tinggi suhu yang digunakan pada proses pengeringan akan menyebabkan kandungan lemak yang ada pada bahan juga semakin meningkat dan kandungan air yang semakin menurun. Didukung dengan penelitian Zuhra et al. (2012), menyatakan bahwa meningkatnya kadar lemak dengan suhu pengeringan yang tinggi dapat disebabkan oleh penurunan kadar air sehingga presentase kadar lemak meningkat. Kadar lemak yang tinggi dapat terjadi sebagai akibat dari rusaknya lemak akibat temperature pengeringan yang relativ tinggi Riansyah et al. (2013).

\section{Kadar Karbohidrat}

Hasil analisis kadar karbohidrat tertinggi (Tabel 1) terdapat pada S2 dengan nilai 10,19\% dan nilai terendah pada S1 dengan nilai 6,32\%. Tingginya nilai kadar karbohidrat berkaitan dengan rendahnya kadar air, kadar abu dan kadar protein. Menurut Winarno (2004), kandungan karbohidrat sangat dipengaruhi oleh faktor kandungan gizi lainnya. Semakin tinggi kandungan protein , lemak, air, dan abu maka semakin rendah kadar karbohidratnya.

\section{Analisis Total Plate count (TPC)}

Hasil uji total mikroba pada (Tabel 2), menunjukan rerata nilai tertinggi terdapat pada $\mathrm{S} 1$ dengan nilai $8.5 \times 10^{4} \mathrm{Cfu} / g$ dan nilai terendah terdapat pada S2 dengan nilai $3.8 \times 10^{4} \mathrm{Cfu} / \mathrm{g}$. Hasil tersebut lebih rendah dibandingkan dengan penelitian Imelda et al. (2018) tentang mutu produk teri (Stolephorus sp.) kering yang menyatakan kandungan Total Plate Count yaitu $1,16 \times 10^{3}$. Rendahnya nilai tersebut diduga karena lama proses pengeringan pada bahan baku gurita diperkirakan selama 1 minggu dibanding dengan penelitian produk ikan teri kering yang hanya selama 3 hari, lamanya proses pengeringan menyebabkan kandungan kadar air yang terdapat pada bahan baku menjadi berkurang sehingga aktifitas mikroorganisme menjadi terhambat.

Berdasarkan SNI 2771:2009 (Cfu/g) standar Total Plate Count (TPC) yaitu maksimal $1 \times 10^{5}$, dalam hal ini bahan baku gurita kering yang dipasarkan di Kabupaten Konawe Utara masih memenuhi standar mutu serta aman untuk dikonsumsi.

\section{KESIMPULAN}

Berdasarkan hasil dan pembahasan maka dapat di simpulkan sebagai berikut :

1. Berdasarkan hasil uji proksimat didapatkan rerata nilai pada kadar protein 19,89\%-17,13\%, kadar abu 13,63-8,11\%, kadar protein 46,99-42,39\%, kadar lemak 5,82-4,28\% dan kadar karbohidrat $10,19-6,32 \%$. 
2. Uji Total Plate Count (TPC) yang di lakukan dengan rerata nilai $8.5 \times 10^{4}-3.8 \times 10^{4} \mathrm{Cfu} / \mathrm{g}$ masih memenuhi standar SNI yang ditetapkan yaitu

\section{DAFTAR PUSTAKA}

Abdurrachim., Yani, E dan Pratoto, A. 2009. Analisis Efisiensi Pengeringan Ikan Nila Pada Pengering Surya Aktif Tidak Langsung. Fakultas Teknik. Universitas Andalas. Padang. 2 (1): 26-27

Adawyah, R. 2007. Pengolahan dan Pengawetan Ikan. PT. Bumi Aksara, Jakarta.

Imelda E.K.S. Silaban. B, Sormin. R.B.D. 2018. Mutu Produk Teri (Stolephorus sp.) Kering Pulau Buru Dengan Metode Pengeringan Surya Tertutup.Jurnal Pengolahan Hasil Perikanan Indonesia. 21(3):543-548.

KKP. 2011. Statistik Perikanan Pelabuhan Perikanan Samudera Kendari. Kendari: Kementerian Kelautan dan Perikanan Direktorat Jenderal Perikanan Tangkap.

KKP. 2012. Statistik Perikanan Pelabuhan Perikanan. KKP, 2018. Gurita Komoditi Andalan PPS Kendari.

Pelabuhan Perikanan Samudera Kendari

Direktorat Jenderal Perikanan Tangkap.

Lambongadil, G.P., Reo, A.R \& Onibala, H. 2013. Studi Mutu Produk Ikan Japuh (Dussumieria acuta C.V.) Asap Kering Industri Rumah Tangga Di Desa Tumpaan Baru Kecamatan Tumpaan. Fakultas Perikanan dan IImu Kelautan. Universitas Samratulangi. Sulawesi Utara. Manado. Jurnal Media Teknologi Hasil Perikanan. 1(2): 12-18.

Listiani N. 2013. Penerapan standar ekspor gurita dan ikan teri perusahaan perikanan di Kendari. Buletin IImiah Litbang Perdagangan, 7(1).

Riansyah, A., Supriadi, A., Nopianti, R. 2013. Pengaruh Perbedaan Suhu Dan Waktu maksimal $1 \times 10^{4} \mathrm{Cfu} / \mathrm{g}$, serta masih aman untuk dikonsumsi.

Pengeringan Terhadap Karakteristik Ikan Asin Sepat Siam (Trichogaster pectoralis) Dengan Menggunakan Oven. Program Studi Teknologi Hasil Perikanan. Fakultas Pertanian. Universitas Sriwijaya Indralaya Ogan llir. Vol II No.01 November 2013.

Thanonkaew, A.,Benjakul, S. and Visessanguan, W. 2006. Chemical Composition and Thermal Property of Cuttlefish (Sepia pharaomis).Journal of Food Composition and Analysis. 19 (2): 591-599.

Winarko, A. 2001. Studi Beberapa Aspek Biologi dan Efisiensi Ekonomi Unit Usaha Perikanan Gurita ( Octopus sp.) [Skripsi] Jurusan Perikanan Fakultas IImu Kelautan dan Perikanan Universitas Hasanuddin Ujung Pandang

Winarno FG. 2004 Kimia Pangan dan Gizi PT. Gramedia Pustaka Utama: Jakarta.

Wirakartakusumah, A. 1992. Perlakuan dan Unit Proses Industri Pangan.Institut Pertanian Bogor.

Yuniarti. N. et al., 2007. Pengaruh penurunan kadar air terhadap perubahan fisiologi dan kandungan biokimia benih eboni (Diospyros celebica Bahk.). Jurnal Penelitian Hutan Tanaman. 5 (3): 191 - 198.

Zuhra, S. dan C. Erlina. 2012. Pengaruh Kondisi Operasi Alat Pengering Semprot Terhadap Kualitas Susu Bubuk Jagung. Jurnal Rekayasa Kimia dan Lingkungan. Universitas Syiah Kuala. 9 (1): 36-44. 